Article

\title{
The Impact of Big Data Technical Skills on Novel Business Model Innovation Based on the Role of Resource Integration and Environmental Uncertainty
}

\author{
Bingqin Dai ${ }^{1,2}$ and Wenquan Liang ${ }^{3, *(\mathbb{D})}$ \\ 1 School of Business Administration, South China University of Technology, Guangzhou 510000, China; \\ 201919900502@mail.scut.edu.cn \\ 2 College School of Finance and Business, Minxi Vocational \& Technical College, Longyan 361000, China \\ 3 School of Resource Engineering, Longyan University, Longyan 361000, China \\ * Correspondence: onethink2002@foxmail.com
}

Citation: Dai, B.; Liang, W. The Impact of Big Data Technical Skills on Novel Business Model Innovation Based on the Role of Resource Integration and Environmental Uncertainty. Sustainability 2022, 14, 2670. https://doi.org/10.3390/ su14052670

Academic Editor: JinHyo Joseph Yun

Received: 24 January 2022

Accepted: 22 February 2022

Published: 24 February 2022

Publisher's Note: MDPI stays neutral with regard to jurisdictional claims in published maps and institutional affiliations.

Copyright: (C) 2022 by the authors. Licensee MDPI, Basel, Switzerland. This article is an open access article distributed under the terms and conditions of the Creative Commons Attribution (CC BY) license (https:// creativecommons.org/licenses/by/ $4.0 /)$.

\begin{abstract}
Taking the dynamic capability theory as the research framework, using a two-stage questionnaire survey and 318 Chinese enterprises as samples, this study investigates the impact mechanism of big data technical skills on novel business model innovation, as well as the mediator of resource integration and the moderator of environmental uncertainty. The hierarchical regression results show that: (1) big data technical skills have a significant positive impact on novel business model innovation; (2) resource integration is a partial mediator between big data technical skills and novel business model innovation; (3) environmental uncertainty regulates the relationship between big data technical skills and resource integration, that is, the higher the environmental uncertainty, the stronger the positive relationship between big data technical skills and resource integration; (4) environmental uncertainty has no significant moderating effect on the mediating role of resource integration between big data technology skills and novel business model innovation. The conclusion of this study develops the driving factors of novel business model innovation and provides theoretical guidance for enterprises to improve the innovative activities of novel business models by using big data technology skills.
\end{abstract}

Keywords: novel business model innovation; big data technical skills; environmental uncertainty; resource integration

\section{Introduction}

The deep integration of digital technology and various industries has brought profound changes to enterprise operations. The opportunities for stakeholders such as customers, suppliers, and investors to participate in enterprise value creation are increasing. All kinds of big data collected by various platforms such as enterprise platforms and mass media provide the main channel for enterprises to put forward value propositions that meet market needs, and big data also changes the way enterprises survive and develop and drives enterprises to innovate their business models. Business model innovation is a system that clarifies value creation, value exchange, and value acquisition $[1,2]$, and is the key for enterprises to realize sustainable development [3,4]. Amit and Zott divided business model innovation into novel type and efficiency type [5]. This study focuses on the novel type of business model innovation, which realizes value creation by redesigning the constituent elements and their combinations. Novel business model innovation can maximize value gains by increasing product value and reducing value creation and value exchange costs [5] to obtain competitive advantages [6]. Li et al. [7] have shown that in the process of implementing novel business model innovation, changes in the external environment and resource conflicts will lead enterprises to face great environmental uncertainty. Therefore, it is of great significance to explore how big data technical skills affect novel business model 
innovation based on resource integration and environmental uncertainty, so as to expand the antecedents of novel business model innovation and guide management practices.

Unfortunately, the current research on business model innovation mainly focuses on model design, change, evolution, implementation, control, and its positive results, and there is still a lack of research on the antecedents of business model innovation $[7,8]$. Previous research has mainly focused on two dimensions: internal factors and external factors. Internal factors mainly relate to strategic decision-making, goal driven, organizational structure adjustment, and other perspectives [9]. External factors mainly relate to new market opportunities, institutional changes, technological innovation, and other perspectives of the industry [5,10]. In general, there has been less discussion about the antecedent factors of novel business model innovation in theoretical circles [8]. At present, due to the extensive use of emerging computing technologies such as cloud computing, big data technology skills have become important abilities within enterprises, which may have a significant impact on the innovation of novel business models [11]. Based on this, this study intends to focus on the impact of big data technical skills on the innovation of novel business models. As a specialized technique in data extraction and cleaning, statistical analysis, machine learning, and internalized programming paradigm, big data technical skills can capture new market demand intelligence from big data [12] to improve the ability of resource integration and value creation, innovate business planning, and improve enterprise performance [13]. Therefore, this study expects that big data technical skills do play a positive role in the novel business model innovations. This study will systematically explore the relationship between big data technical skills and novel business model innovation.

In addition, if big data technical skills have an impact on novel business model innovation, how does this impact occur? The existing research does not give a clear answer to this question. Ciampi et al. [14] used survey data from 253 UK companies to confirm that big data analysis capabilities have a positive impact on business model innovation. Sun and Liu [15] used samples of 208 Chinese companies and used multiple regressions to empirically show that big data technology skills positively moderate the impact of novel business model innovation on new product development. Ahmed et al. [16] used 856 questionnaires from the pharmaceutical industry in South Asian countries as a sample, and empirically confirmed that technological progress can reduce corporate operational risks and improve corporate innovation capabilities. However, the existing research has ignored the ways in which big data technical skills affect the integration of resources in the innovation process of novel business models. As the main source of competitive advantage among enterprises, the acquisition, allocation, and combination of resources will affect the innovation and competitiveness of enterprises $[17,18]$.

Based on the dynamic capability theory [19], this study found the key to open the "black box" between big data technical skills and novel business model innovationresource integration [17]. Dynamic capability theory points out that in order to adapt to the market change process [19], enterprises will involve activities such as enterprise integration, the reallocation of resources, and the release of resources [18]. If an enterprise can meet the new market demand faster and better than its competitors, it can gain a competitive advantage in the market [20]. Resource integration can help companies quickly adapt to a new market environment [18]. Accordingly, this study argues that resource integration is likely to act as a mediating variable for big data technical skills to influence novel business model innovation. At the same time, in order to enhance the situational research of big data technical skills, this study proposes that environmental uncertainty may be the boundary condition affecting the relationship between big data technical skills and resource integration. As an important external scenario variable [21], environmental uncertainty means that enterprises cannot accurately perceive the external environment [22]. Skordoulis et al. empirically showed that changes in the environment will affect the competitive advantage of enterprises through 225 valid questionnaires investigating large and medium-sized Greek companies [23]. Using quantitative data from mid-level managers and senior managers 
in 320 Chinese medical institutions, Chen and Zhang empirically demonstrated that the relationship between the relative advantage and willingness to use mHealth services was positively moderated by environmental uncertainty [24]. Considering that enterprises may rely more on the assistance of big data technical skills to integrate resources and make corresponding decisions under the scenario of environmental uncertainty, environmental uncertainty may affect the effectiveness of big data technical skills. Therefore, this study will also test the moderator of environmental uncertainty between big data technical skills and resource integration.

In brief, the purpose of this research is to explore whether big data technical skills have a positive effect on novel business model innovation, whether resource integration has a mediating role between big data technical skills and novel business model innovation, and whether environmental uncertainty plays a moderating role. Referring to previous relevant research, based on the dynamic capability theory [19] and the value co-creation theory [25], this study explains how big data technical skills affect novel business model innovation through resource integration. This perspective helps to deepen the understanding of the action mechanism of big data technical skills. At the same time, this study focuses on the context of big data technical skills and constructs a regulated intermediary model according to relevant theories which helps to reveal the internal process and boundary conditions of the role of big data technical skills, enrich the research results regarding the effect of antecedents on novel business model innovation, and provide some practical guidance and enlightenment for enterprises to enable them to implement business model innovation activities. The research framework of this paper is shown in Figure 1.

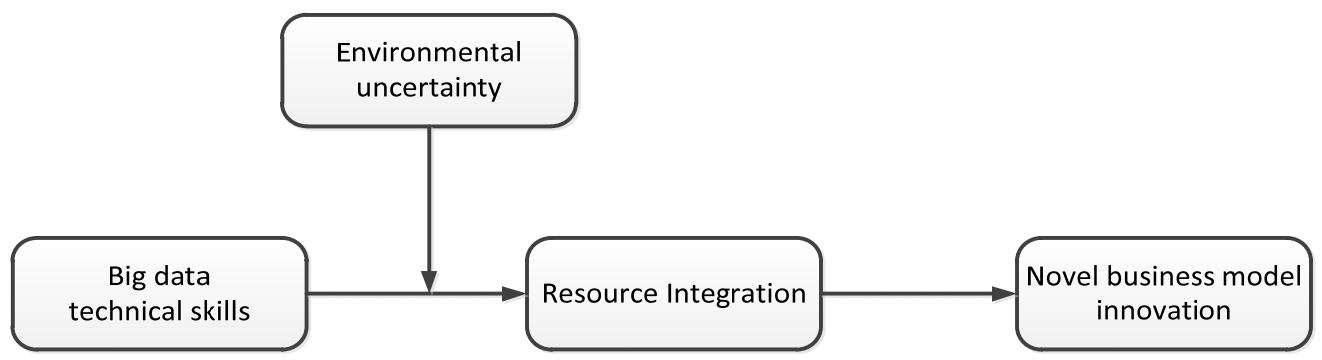

Figure 1. The framework of this research.

\section{Literature Review and Research Hypothesis}

\subsection{Big Data Technical Skills and Novel Business Model Innovation}

According to the dynamic capability theory, big data technical skills are the ability of enterprises to obtain internal and external data resources, as well as the ability to capture business opportunities and predict market development trends by analyzing data [26]. Bharadwaj et al. [27] believed that big data technical skills can realize the application of data acquisition, sorting, management, and reorganization, and bring support for enterprises to choose correct value propositions and value creation that cannot be realized by traditional information systems. Ransbotham and Kiron [28] pointed out that data analysts can obtain information of great value to enterprises from big data analysis through the flexible application of technical skills and bring support to enterprise innovation through the processing and rational allocation of data resources.

Pesqueira et al. [29] believed that big data infrastructure, analyst capabilities, and enterprise decision making in the data economy are key capabilities across organizations and play a key role in business model innovation. This paper speculates that big data technical skills may promote novel business model innovation.

Firstly, based on the dynamic capability theory [19], big data technical skills can affect the innovation capabilities of enterprises by analyzing, integrating, reconstructing, and transforming the obtained data into information knowledge to improve the adaptability of enterprises to an uncertain environment [30]. Big data has the characteristics of various types and obtains complex results. The traditional data analysis techniques cannot clarify 
huge and complex data, nor can they timely and effectively capture information and knowledge of practical value to enterprises from big data [26]. Mikalef and Krogstie et al. [31] used the data from 202 surveys from Norwegian companies to empirically show that big data capabilities positively affect the perception, capture, and transformation capabilities of enterprises. Therefore, if an enterprise does not master the technical skills of big data and only uses traditional data analysis, the big data acquired by the enterprise will not be able to help the enterprise improve its ability to deal with the drastic changes in the internal and external environment, and big data will lose its value as a strategic resource. Therefore, big data technical skills can help enterprises obtain valuable information from messy big data and improve the ability of business model innovation.

Secondly, big data itself is an important strategic resource which can promote enterprise service innovation and product innovation for enterprises [32]. Through scientific analysis and the sorting of data, big data technical skills can enable huge and complex data to become organized and knowledgeable, facilitate the dissemination of valuable knowledge information contained in big data, and enhance the ability of enterprises to deal with changes in the external environment [33]. The reasons are as follows: (1) big data technical skills can quickly compare and analyze complex data from multiple sources and clarify the relationship between data; (2) big data technical skills can promote an understanding of the changing trends in consumer demand, so as to provide accurate value proposition for enterprises; (3) through the analysis of resource data, big data technical skills can help enterprises reselect partners and redesign product production processes according to value propositions to innovate a more scientific and efficient way of value creation.

Finally, big data technical skills have a greater impact on enterprise innovation [34]. At present, the environment faced by enterprises is changing rapidly. The rapidly changing environment will force enterprises to adopt innovative ways to adapt to it, which may make the original important resources unimportant, and will require enterprises to acquire new resources and reorganize resources [35]. It is speculated that big data technology skills may have a positive effect on novel business model innovation. Based on the above analysis, this paper puts forward the first hypothesis:

Hypothesis 1 (H1). Big data technical skills have a positive effect on novel business model innovation.

\subsection{Mediating Effect of Resource Integration}

Resource integration is a process involving the rational combination and allocation of resources to form new capabilities [17]. Based on the dynamic capability theory, it can be seen that big data technical skills can affect the efficiency and effect of enterprise innovation [30]. Especially when the internal and external environment, the enterprise's operation model, profitability, and the importance of various resources change significantly [35], enterprises can quickly recognize the attributes and importance of resources by analyzing the various resources related to business model innovation through big data technical skills to enhance the ability of enterprise resource integration [36]. Wirtz et al. believed that the essence of the process related to new business models is the process of resetting, reallocating, continuously optimizing, and reorganizing new and existing resources [8]. To realize the efficient and reasonable combination of resources, it is necessary to identify the attributes and usages of resources. Big data technical skills can well meet this requirement. Therefore, this paper speculates that resource integration acts as a mediator between big data technical skills and novel business model innovation. The reasons are as follows.

Firstly, big data technical skills can identify the changing trends in market demand through the analysis of market data to help enterprises choose the correct value proposition [25]. From the perspective of the value co-creation theory, big data technical skills can quickly identify the attributes and functions of resources provided by key partners through the analysis of the resources owned by enterprises to accelerate the allocation of resources required by enterprises in the process of producing innovative products [37], and provide information support for enterprises to build a new value co-creation platform to innovate 
enterprise value creation and improve the ability of value creation within enterprises [38]. In a new environment, big data technical skills can help enterprises choose the most suitable value transmission channels and value acquisition methods by analyzing the effectiveness of different value transmission resources. Therefore, big data technical skills can have an impact on novel business model innovations through the analysis, recombination, and allocation of resources. Empirical research has shown that big data technical skills have a significant positive impact on resource integration.

Secondly, from the perspective of dynamic capability [19], (1) resource integration itself belongs to dynamic capability [39]; (2) the purpose of designing novel business model is to seize the opportunity from the rapidly changing external environment. Dynamic capabilities can help enterprises achieve the goal of business model innovation and transformation; (3) the novel business model needs new resources and new resource combinations, and resource integration can meet this demand. The higher the dynamic capability, the more innovative the business model [39]. It can be seen that the higher the resource integration capability, the higher the degree of innovation of the novel business model. It is therefore speculated that there may be a positive relationship between resource integration and novel business model innovation.

To sum up, this study believes that big data technical skills may affect novel business model innovation through resource integration. Therefore, this study puts forward the second hypothesis:

Hypothesis 2 (H2). Resource integration mediates between big data technical skills and novel business model innovation.

\subsection{The Moderating Role of Environmental Uncertainty}

Environmental uncertainty means that enterprises cannot accurately predict the changes in the external environment, which reflects the stability of the external environment [40]. Research has shown that environmental factors have a great impact on enterprise strategies $[7,41]$. When enterprises face high environmental uncertainties, the development path of the consumer market, the industrial policies, and the digital technology in their industry becomes more unpredictable, and the difficulty of resource integration further increases [42]. The environmental uncertainty of the industry in which the enterprise is located will affect the resource acquisition ability of the enterprise, and the data obtained by the enterprise will be relatively messy and even incomplete, which increases the difficulty for enterprise managers to judge the market development trends. According to the value co-creation theory, under the uncertainty of industry policy, digital technical and resource supply capacity, it will be more difficult for consumers, suppliers, key partners, and other stakeholders to participate in product design, product production, and product sales [43]. In this case, it is necessary to provide managers with valuable data and information for enterprise development, enhance the enterprise's resource integration ability, and quickly respond to environmental uncertainty. Big data technical skills can not only help enterprises obtain data information in a complex environment, but they also sort out disordered big data, capture valuable information resources, and reduce the negative impact of environmental uncertainty on enterprise resource integration. Therefore, big data technical skills can improve the resource integration ability of enterprises under the conditions of environmental uncertainty. Environmental uncertainty can be regarded as an external factor that stimulates the effect of big data technical skills.

On the contrary, when enterprises perceive that the uncertainty of the environment is low, enterprises face fewer challenges regarding novel business model innovation. It is also easier for enterprises to obtain comprehensive market information, technical information, resource supply information and other information, identify and judge market development trends, and make good use of market opportunities [44]. Moreover, the data obtained by enterprises when the environmental uncertainty is low have a good regularity, and managers themselves may be able to obtain information of great value to enterprises from 
big data [28]. To sum up, a high environmental uncertainty will enhance the positive impact of big data technical skills on resource integration. Based on this, this study puts forward the third hypothesis:

Hypothesis 3 (H3). Environmental uncertainty has a positive effect on big data technical skills and resource integration.

Combined with hypotheses $\mathrm{H} 2$ and $\mathrm{H} 3$, this study further predicts that the mediating effect of resource integration between big data technical skills and novel business model innovation will be regulated by environmental uncertainty. Specifically, in the case of high environmental uncertainty, the relationship between big data technical skills and resource integration will be stronger. If resource integration encounters difficulties, it will stimulate enterprises to improve their big data technical skills to improve their resource integration ability and ensure the innovation process of a novel business model. Resource integration transmits the effect of big data technical skills on novel business model innovation. On the contrary, when the market demand operates under a low environmental uncertainty [45], this will reduce the sensitivity of resource integration to big data technical skills and weaken the stimulating effect of big data technical skills on business model innovation. Based on this, this study puts forward the fourth hypothesis:

Hypothesis 4 (H4). Environmental uncertainty will moderate the mediating effect of resource integration between big data technical skills and novel business model innovation. The higher the environmental uncertainty, the stronger the mediating role, and vice versa.

\section{Research Method}

\subsection{Sample and Data Collection}

As suggested by Podsakoff et al. [46], in order to reduce the common method bias, this study adopted a two-stage questionnaire survey method to investigate 736 Chinese enterprises. This study conducted a pre-test prior to a formal survey of firms. The pretest and formal surveys were conducted in the form of vertical pairing. The respondents were middle-level or senior managers of the company, and one enterprise only filled in one questionnaire. The respondents in the two stages were the same group, and each questionnaire was coded so that the two rounds of questionnaires could be paired. The first stage was used to collect big data technical skills, resource integration, and environmental uncertainty data. The second stage was used to collect novel business model innovation data. The respondents in the second stage were the respondents in the first stage. The questionnaire was divided into three parts: the first part contained the screening questions, and those who were identified as not meeting the requirements for filling in the form were terminated from answering the questionnaire; the second part contained the descriptive questions about the characteristics of the interviewed companies and individuals; the third part contained the scale to measure the variables of this study. In order to ensure the quality of the questionnaire, the research group indicated that the survey was anonymous and the data obtained were only used for academic research.

This study mainly discussed the specific mechanism of big data technical skills, resource integration, and environmental uncertainty on novel business model innovation. With the popularization and development of digital technologies such as the Internet, business model innovation is no longer limited to high-tech enterprises. The business models of many traditional enterprises are affected by digital and technical factors, and they have also begun to actively transform or have successfully transformed. According to the actual needs of the research problem, this study did not limit the specific types of research enterprises.

This study conducted a pre-test survey from May to August 2021. The pre-test questionnaires were mainly distributed online and via e-mail. A total of 215 questionnaires were distributed. After two stages of questionnaire distribution, 133 questionnaires were recovered. 
After excluding the invalid questionnaires, 96 valid questionnaires were finally obtained. Through the test, it was known that Cronbach's $\alpha$ coefficient of each potential variable is more than 0.8. According to Nunnally [47], the internal consistency of the variables was good. The KMO value was more than 0.8 , and Bartlett's spherical test value was significant (SIG. <0.001). Therefore, the questionnaire of this study could be formally determined.

A formal survey was conducted as part of this study from September to December 2021. The formal questionnaires were mainly distributed by e-mail. A total of 521 questionnaires were distributed. After two stages of questionnaire distribution, a total of 386 questionnaires were recovered. After excluding the invalid questionnaires, 318 valid questionnaires were finally obtained, and the effective recovery rate was $63.6 \%$. The specific descriptive statistical results of the sample are shown in Table 1.

Table 1. Descriptive statistics of interviewed companies and personal characteristics.

\begin{tabular}{|c|c|c|c|c|c|c|c|}
\hline \multicolumn{4}{|c|}{ Enterprise Characteristics } & \multicolumn{4}{|c|}{ Characteristics } \\
\hline Category & Classification & Samples & Percent (\%) & Category & Classification & Samples & Percent (\%) \\
\hline \multirow{5}{*}{$\begin{array}{l}\text { Industry } \\
\text { category }\end{array}$} & Manufacturing & 125 & 39.3 & \multirow{2}{*}{ Position } & Midlevel managers & 108 & 34 \\
\hline & Service industry & 79 & 24.8 & & Senior managers & 210 & 66 \\
\hline & Retail industry & 28 & 8.8 & \multirow{3}{*}{ Sex } & Male & 214 & 67.3 \\
\hline & Farming & 12 & 3.8 & & Female & 104 & 32.7 \\
\hline & Others & 74 & 23.3 & & Below college & 12 & 3.8 \\
\hline \multirow{3}{*}{$\begin{array}{l}\text { Enterprise } \\
\text { size }\end{array}$} & $\begin{array}{l}200 \text { people } \\
\text { and below }\end{array}$ & 118 & 37.1 & \multirow[t]{3}{*}{ Education } & College degree & 81 & 25.5 \\
\hline & 201-500 people & 68 & 21.4 & & Bachelor's degree & 173 & 54.4 \\
\hline & $\begin{array}{l}\text { More than } \\
500 \text { people }\end{array}$ & 132 & 41.5 & & Master's degree & 50 & 15.7 \\
\hline \multirow{2}{*}{$\begin{array}{l}\text { Years of es- } \\
\text { tablishment }\end{array}$} & 3 years and below & 12 & 3.8 & \multirow{8}{*}{ Age } & Doctor's degree & 2 & 0.6 \\
\hline & More than 3 years & 306 & 96.2 & & $\begin{array}{l}25 \text { years old } \\
\text { and below }\end{array}$ & 20 & 6.3 \\
\hline \multirow{6}{*}{ Headquaters } & Northeast & 1 & 0.3 & & 26-35 years old & 127 & 39.9 \\
\hline & East China & 168 & 52.8 & & $36-45$ years old & 138 & 43.3 \\
\hline & North China & 18 & 5.7 & & $46-55$ years old & 27 & 8.5 \\
\hline & South China & 118 & 37.1 & & $\begin{array}{l}56 \text { years old } \\
\text { and above }\end{array}$ & 6 & 1.9 \\
\hline & Southwest & 10 & 3.1 & & & & \\
\hline & Northwest & 3 & 0.9 & & & & \\
\hline
\end{tabular}

\subsection{Measure}

The scales used in this study were from the mature scale of high-end journals, and the variables involved were evaluated by the Likert level5 scale, in which 1 represents very strong disagreement and 5 represents very strong agreement.

\subsubsection{Big Data Technical Skills}

This study adopted the scale of five items revised by Gupta et al. [12], with typical items such as the hiring of new employees who already have big data analysis skills and big data analysts who have the correct skills to successfully complete their work. In this study, the internal consistency coefficient was 0.92 .

\subsubsection{Resource Integration}

This study adopted a scale developed by Sirmon et al. [17] with 3 dimensions and 11 items, with typical items such as slightly changed the combination of its resources and necessary investment in its supporting resources. In this study, its internal consistency coefficient was 0.91 .

\subsubsection{Environmental Uncertainty}

This study used a 4-dimension scale developed by Miller [48] and revised by Jansen et al. [49] with typical items such as the change degree of external environment is 
very drastic and customers often put forward new demands for products (services). In this study, its internal consistency coefficient was 0.85 .

\subsubsection{Novel Business Model Innovation}

This study adopted the scale of 9 items developed by Zott and Amit [50], with typical items such as providing new products, services and information combination and constantly introducing new partners. In this study, the internal consistency coefficient was 0.90 .

\subsubsection{Control Variables}

Referring to previous studies on business model innovation, this study set 7 variables as the control variables, such as the number of years of establishment, industry, scale, position, age, gender, and the education level of the applicant.

\section{Empirical Results and Analysis}

\subsection{Common Method Bias Test}

Although this study adopted a multi-stage method to collect data, it could not completely eliminate the common method deviation. Therefore, based on the suggestions of Podsakoff et al. [46], this paper adopted a variety of methods to detect the potential common method deviation. First, Harman's one-factor test showed that the maximum factorial variance explained without rotation was $32.627 \%$, which was less than the suggested value of $50 \%$. In addition, this study also used the common method factor to further test the common method bias. The results of the analysis showed that after adding the common method factor, the fit of the five-factor model was not significantly improved compared to that of the four-factor model (the decrease in RMSEA and RMR was less than 0.01, and the increase in CFI and NFI was less than 0.1. The results are shown in Table 2). In conclusion, the common method bias of this study was within acceptable limits.

Table 2. Confirmatory factor analysis results $(n=318)$.

\begin{tabular}{cccccc}
\hline Model & $\chi \mathbf{2} / \mathbf{d f}$ & CFI & RMR & NFI & RMSEA \\
\hline Five-factor model (A, BDTS, RI, EU, NBMI) & 1.206 & 0.987 & 0.037 & 0.929 & 0.025 \\
Four-factor model (BDTS, RI, EU, NBMI) & 1.302 & 0.924 & 0.044 & 0.915 & 0.031 \\
Three-factor model (BDTS + RI, EU, NBMI) & 2.432 & 0.897 & 0.064 & 0.839 & 0.067 \\
Two-factor model (BDTS + RI + EU, NBMI) & 3.311 & 0.830 & 0.071 & 0.777 & 0.085 \\
one-factor model (BDTS + RI + EU + NBMI) & 4.128 & 0.769 & 0.084 & 0.720 & 0.099 \\
\hline
\end{tabular}

Note: A stands for common factor; BDTS stands for big data technical skills; NBMI stands for novel business model innovation; RI stands for resource integration; EU stands for environmental uncertainty.

\subsection{Validity Test}

This study used a factor analysis to test the discriminant validity of the four variables of big data technical skills, resource integration, environmental uncertainty, and business model innovation. The test results are shown in Table 2. It can be seen from the test results that the fitting index of the four-factor model was significantly better than other models, which indicates that the four variables in this study had a good discriminant validity.

\subsection{Descriptive Statistical Analysis}

In this study, the correlation coefficient, mean, and standard deviation of various variables such as industry, years of establishment of the company (YoE), location of company headquarters (LoH), and the position, gender, education level, and age of the respondents are shown in Table 3. It can be seen from Table 3 that big data technical skills and novel business model innovation had a significant positive correlation $(r=0.56, p<0.01)$; big data technical skills and resource integration had a significant positive correlation $(r=0.55$, $p<0.01)$; and there was a significant positive correlation between resource integration and novel business model innovation $(r=0.56, p<0.01)$. 
Table 3. The mean, standard deviation, and correlation coefficients of each variable $(n=318)$.

\begin{tabular}{|c|c|c|c|c|c|c|c|c|c|c|c|}
\hline & 1 & 2 & 3 & 4 & 5 & 6 & 7 & 8 & 9 & 10 & 11 \\
\hline $\begin{array}{c}\text { Industry } \\
\text { YoE }\end{array}$ & $\begin{array}{c}1 \\
-0.01\end{array}$ & & & & & & & & & & \\
\hline Position & 0.05 & 0.01 & & & & & & & & & \\
\hline Gender & -0.02 & $-0.17^{* *}$ & -0.01 & & & & & & & & \\
\hline $\mathrm{LoH}$ & 0.09 & -0.05 & -0.01 & -0.06 & & & & & & & \\
\hline Education & -0.02 & 0.11 * & -0.04 & -0.06 & 0.12 * & & & & & & \\
\hline Age & -0.07 & $0.35^{* *}$ & 0.07 & $-0.21 * *$ & 0.09 & $0.20 * *$ & & & & & \\
\hline NBMI & -0.06 & 0.05 & -0.04 & -0.04 & -0.08 & $-0.11 *$ & 0.03 & $(0.86)$ & & & \\
\hline BDTS & 0.02 & $0.15^{* *}$ & 0.02 & -0.01 & -0.01 & -0.05 & 0.08 & $0.56^{* *}$ & $(0.87)$ & & \\
\hline RI & 0.01 & $0.12 *$ & 0 & -0.06 & -0.06 & 0.03 & 0.07 & 0.56 ** & $0.55^{* *}$ & $(0.88)$ & \\
\hline EU & -0.08 & 0.13 * & -0.10 & $-0.13^{*}$ & -0.04 & -0.01 & 0.10 & $0.39 * *$ & $0.33 * *$ & $0.53 * *$ & $(0.82)$ \\
\hline Mean & 2.47 & 3.35 & 2.33 & 1.33 & 2.93 & 2.84 & 2.60 & 3.95 & 3.89 & 3.88 & 4.046 \\
\hline Std. & 1.59 & 0.89 & 1.07 & 0.47 & 1.06 & 0.75 & 0.81 & 0.56 & 0.69 & 0.53 & 0.608 \\
\hline
\end{tabular}

Note: The numbers in the diagonal brackets are the internal consistency coefficients of each scale, and ${ }^{* *}$, and * represent $p<0.01$, and $p<0.05$, respectively.

\subsection{Hypothesis Test}

\subsubsection{Direct effect}

Hierarchical regression was used to test the relationship between big data technical skills and novel business model innovation through SPSS 23.0. The specific steps were as follows. First, the novel business model innovation was taken as the dependent variable, and the industry, the number of years since the company was established, the location of the company's headquarters, the position, gender, education level, and age of the person filling the form were put into the regression model as control variables. The regression results are shown as M1 in Table 4. Next, the big data technical skills were put into the regression model as independent variables, and the regression results are shown as M2 in Table 4. It can be seen from M2 that big data technical skills had a significant positive impact on the novel business model innovation $(\beta=0.480, p<0.001)$. Therefore, H1 was verified.

Table 4. Hierarchical regression test results.

\begin{tabular}{|c|c|c|c|c|c|c|c|c|}
\hline \multirow{2}{*}{ Category } & \multicolumn{4}{|c|}{ Novel Business Model Innovation } & \multicolumn{4}{|c|}{ Resource Integration } \\
\hline & M1 & M2 & M3 & M4 & M5 & M6 & M7 & M18 \\
\hline Industry & -0.023 & -0.029 & -0.031 & -0.028 & -0.010 & 0.003 & 0.016 & 0.015 \\
\hline NYE & -0.035 & -0.051 & -0.056 & -0.052 & -0.031 & 0.014 & -0.017 & -0.019 \\
\hline Position & -0.031 & -0.036 & -0.033 & -0.029 & -0.003 & -0.008 & 0.019 & 0.019 \\
\hline Gender & -0.055 & -0.065 & -0.036 & -0.016 & -0.070 & -0.080 & -0.006 & -0.013 \\
\hline Headquarter & -0.044 & -0.042 & -0.026 & -0.018 & -0.046 & -0.044 & -0.035 & -0.026 \\
\hline Education & -0.107 & -0.073 & -0.090 & -0.115 & 0.014 & 0.048 & 0.057 & 0.060 \\
\hline Age & 0.050 & -0.008 & 0.005 & 0.021 & 0.051 & 0.010 & -0.002 & -0.006 \\
\hline BDTS & & $0.480^{* * *}$ & $0.310^{* * *}$ & & & $0.478^{* * *}$ & $0.368^{* * *}$ & $0.355^{* * *}$ \\
\hline RI & & & $0.358^{* * *}$ & $0.556^{* * *}$ & & & & \\
\hline $\begin{array}{l}\text { EU } \\
\text { moderate }\end{array}$ & & & & & & & $0.343^{* * *}$ & $\begin{array}{c}0.347^{* * *} \\
0.100 *\end{array}$ \\
\hline $\mathrm{R}^{2}$ & 0.028 & 0.342 & 0.433 & 0.342 & 0.014 & 0.316 & 0.447 & 0.456 \\
\hline$\Delta \mathrm{R}^{2}$ & 0.028 & 0.314 & 0.091 & 0.314 & 0.014 & 0.302 & 0.131 & 0.009 \\
\hline $\mathrm{F}$ & 1.271 & $20.112^{* * *}$ & $26.093^{* * *}$ & $20.070 * * *$ & 0.624 & $17.807^{* * *}$ & $27.620^{* * *}$ & $25.704^{* * *}$ \\
\hline & MV & Level & Effect & SE & Boot95\%CI & INDEX & SE & Boot $95 \%$ CI \\
\hline CIE & EU & Low & 0.0983 & 0.0281 & {$[0.0460,0.1557]$} & 0.0358 & 0.0205 & {$[-0.0009,0.0805]$} \\
\hline & & High & 0.1558 & 0.0340 & {$[0.0962,0.2307]$} & & & \\
\hline
\end{tabular}

Note: CIE stands for Conditional Indirect Effect, MV stands for Moderating Variable, NYE stands for Number of years of establishment and EU stands for Environmental Uncertainty. ${ }^{* * *},{ }^{*}$ denote $p<0.001$ and $p<0.05$ respectively.

\subsubsection{Mediating Effect of Resource Integration}

Baron and Kenny [51]'s intermediary test method was used to test the mediating effect of resource integration between big data technical skills and novel business model innovation. The specific steps were as follows. Firstly, the direct effect was tested (see M2 in Table 4), and the results were supported by H1. Secondly, the relationship between big data technical skills and resource integration was tested. The test results are shown in M6 
of Table 4. Big data technical skills had a significant positive impact on resource integration $(\beta=0.478, p<0.001)$. Then, the relationship between resource integration and business model innovation was tested, and the test results are shown in M4 of Table 4 . Resource integration had a significant positive impact on novel business model innovation $(\beta=0.556$, $p<0.001)$. Finally, on the basis of M1 and M2, intermediary variables were added for regression, and the test results are shown in $\mathrm{M} 3$ of Table 4 . The regression coefficient of big data technical skills on novel business model innovation decreased $(\beta=0.310, p<0.001)$. The effect of resource integration on novel business model innovation was significant $(\beta=0.358, p<0.001)$. This suggests that resource integration played a partial mediating role between big data technical skills and novel business model innovation. Therefore, $\mathrm{H} 2$ was confirmed.

\subsubsection{Moderating Effect}

Hierarchical regression was used to test the moderating effect of environmental uncertainty in four-factor models, in which the moderating effect of big data technical skills and environmental uncertainty is the product of the two standardized products. Firstly, taking resource integration as the dependent variable, the variables were controlled layer by layer in the regression model. The regression results are shown as M5 in Table 4. Secondly, the independent variable big data technical skills were added, and the results are shown in M6 in Table 4. Thirdly, environmental uncertainty adjustment variables were added, and the results are shown in M7 of Table 4. Finally, the moderating effect of big data technical skills and environmental uncertainty was added to the regression model, and the results are shown as M8 Table 4. The coefficient of moderate term was significant $(\beta=0.100, p<0.05)$, indicating that environmental uncertainty played a positive moderator between big data technical skills and resource integration. In order to further clarify the moderating role of environmental uncertainty, this study drew the relationship between big data technical skills and resource integration at the level of the mean of environmental uncertainty plus one standard deviation (+SD) and minus one standard deviation (-SD) (as shown in Figure 2). The simple slope results showed that the slope of the line with high environmental uncertainty $(\gamma=0.436, p<0.001)$ was larger than the slope of the line with low environmental uncertainty $(\gamma=0.274, p<0.001)$, indicating that environmental uncertainty played a positive moderating role; that is, the higher the environmental uncertainty, the stronger the positive impact of big data technical skills on resource integration. Therefore, H3 was verified.

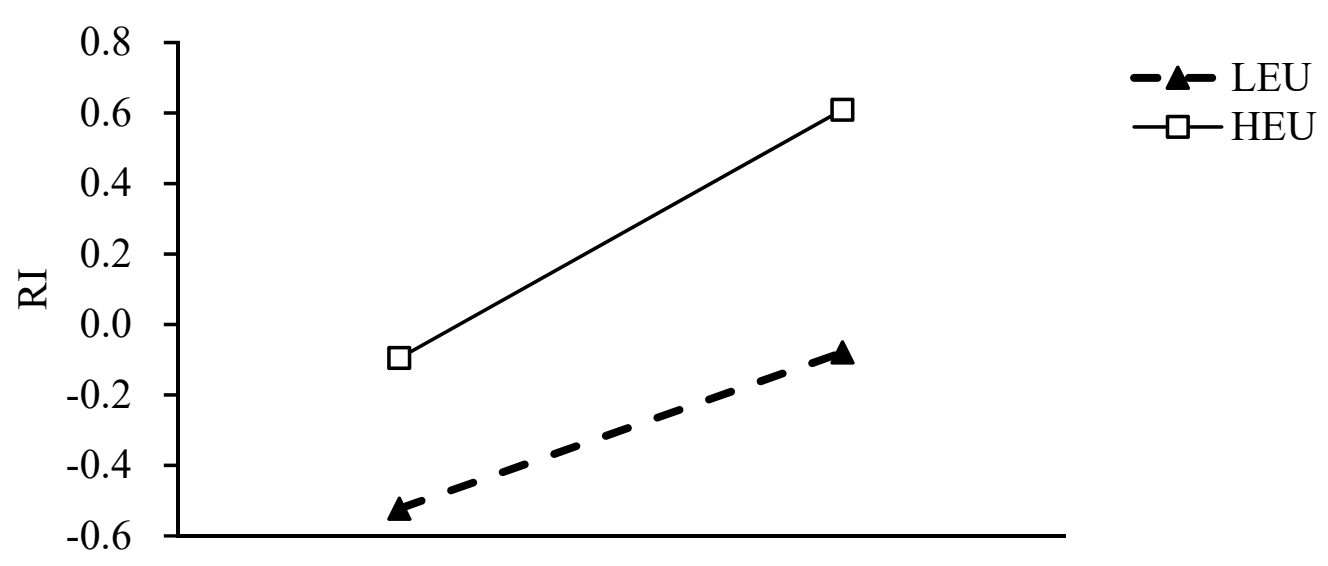

Figure 2. Moderating effects of environmental uncertainty, in which RI, LBDTS, HBDTS and LEU, HEU represent resource integration, low and high big data technical skills, and low and high environmental uncertainty, respectively. 


\subsubsection{Moderating the Mediating Effect Test}

In this study, model 7 in the Process macro program in SPSS was used to test the mediating effect of the moderator. The results are shown in the lower part of Table 4. When the environmental uncertainty was low, the indirect effect of big data technical skills on business model innovation through resource integration was significant $(b=0.0983$, Boot $95 \%$ CI does not include 0 ). When the environmental uncertainty was high, the indirect effect of big data technical skills on business model innovation through resource integration was significant ( $b=0.1558$, boot $95 \% \mathrm{CI}$ does not include 0 ). None of the above confidence intervals (CIs) contained 0 , indicating that the indirect effect of big data technical skills through resource integration was significant regardless of whether the environmental uncertainty was high or low. In response to this situation, Preacher et al. [52] believed that the condition for the existence of an intermediary variable is that at different levels of the moderator variable, one of the indirect effects is significant and the other is not. According to the judgment method of Preacher et al. [52], it is impossible to judge the existence of the intermediary variable. Therefore, Hayes [53] believed that further judgment can be made with reference to the INDEX indicator. As can be seen from the data at the bottom of Table 4 , the INDEX value was 0.0358 , the confidence interval was [ $-0.0009,0.0805]$, and 0 was not included, indicating that environmental uncertainty regulated the mediating effect of resource integration between big data technical skills and novel business model innovation. Therefore, $\mathrm{H} 4$ was not supported.

\section{Discussion and Conclusions}

Although the existing research has indicated that big data technical skills can have a positive impact on enterprises, what is the relationship between big data technical skills and novel business model innovation? What is the mechanism? Existing research on these issues is still relatively lacking. In response to the above problems, this paper conducted a study on the relationship between big data technical skills and novel business model innovation through questionnaires at two different time points. Specifically, based on the theory of dynamic capabilities, this study used empirical data to test the direct effect of big data technical skills on novel business model innovation, the mediate effect of resource integration, and the impact of environmental uncertainty on big data technical skills and novel business model innovation, the moderating effect between resource integration and the moderating effect of environmental uncertainty on the mediate effect of resource integration. The empirical analysis results supported the four hypotheses proposed in this study.

\subsection{Discussion}

Firstly, this study confirmed that big data technical skills are an important factor influencing the innovation of the novel business model. The existing literature points out that technical innovation [6] and the mobility of resources [9] (including human resources, knowledge resources, etc.) all have an impact on business model innovation. However, there is still a lack of an empirical test for the relationship between big data technical skills and novel business model innovation. Ahmed et al. [16] believed that technological progress can improve the operation ability and innovation ability of enterprises. As an important technical resource, big data technical skills can enhance the ability of enterprises to acquire, integrate, and process data, assist enterprises to capture valuable information from disordered big data [54], and enhance the open innovation capability of enterprises [55,56]. Open innovation can not only provide more opportunities for enterprises to eliminate information islands $[57,58]$, but it can also promote knowledge transfer and scientific and technological cooperation among enterprises, open up a new path of technological innovation [59], reduce innovation costs [60], and improve the ability of enterprises to meet market demand [61]. Therefore, technological innovation is an important influencing factor for business model innovation within enterprises [62], and it provides important support for business model innovation within enterprises. Accordingly, this study speculated that 
enterprise big data technical skills had important implications for novel business model innovation. Based on this, this study focused on the impact of big data technical skills. The empirical test results showed that big data technical skills had a significant positive predictive effect on novel business model innovation. Business model itself is a system of value creation activities, which has a direct impact on enterprise performance [2]. Therefore, the results of the research are consistent with Olabode et al. [13], showing that big data analysis abilities have an important impact on enterprise performance.

Secondly, this study found that resource integration had a mediating role between big data technical skills and novel business model innovation. The reason why big data technical skills will have an impact on novel business model innovation is that that this skill may affect the resource integration ability of enterprises, and then may have an impact on novel business model innovation. In view of this, based on the dynamic capability theory [30] and the value co-creation theory [37,38], this study empirically tested the role of resource integration between big data technical skills and novel business model innovation. The test results confirmed that resource integration played a partial mediating role between big data technical skills and novel business model innovation.

Finally, this study discussed the boundary conditions of the role of big data technical skills from the perspective of environmental uncertainty. The existing research on big data technical skills has focused on the big data technical skills themselves, and there is a lack of discussion on external influencing factors [42]. In today's complex and volatile environment, the business model of an enterprise changes over time, creating a dynamic state of business model [63]. In this situation, open innovation has become an important strategic choice for companies [63], and big data analytics can support open innovation [57,64]. Based on this, this study discussed the position and role of environmental uncertainty between big data technical skills, resource integration, and novel business model innovation. The empirical results showed that environmental uncertainty played a moderating role between big data technical skills and resource integration and regulated the mediate effect of resource integration; that is, the higher the environmental uncertainty, the more big data technical skills can improve the ability of resource integration, and then improve the innovation of novel business model. Gupta and George [12] pointed out that under the uncertain environment, enterprises rely more on big data analysts to use analysis tools to capture valuable market development trend information from the big data obtained by enterprises, so as to use resources with advantages when carrying out innovation in technology, system, product and ecology $[18,24]$ and improve the resource integration ability of enterprises. This empirical result directly responded to Skordoulis et al. [23] that changes in the environment will affect the competitive advantage of enterprises, and Sirmon et al. [17] that enterprises can continuously maintain their competitive advantage and value creation ability by improving their ability to allocate, combine and develop resources.

\subsection{Theory Implication}

The results of this study have three facets. (1) This study focused on the antecedent variables of novel business model innovation, verified the promotion of big data technical skills on novel business model innovation, enriched the antecedent research results related to the effects of novel business model innovation, and provided some inspiration for follow-up researchers in this field. (2) It provides a theoretical explanation perspective for the problem "why big data technical skills affect novel business model innovation". This study explored this problem from the perspective of dynamic capability theory [19] and value co-creation theory [25] and interpreted the new problem of the action mechanism of big data technical skills on novel business model innovation from a mature perspective. (3) It established that the impact of big data technology skills on resource integration is also affected by certain conditions, such as the situational factor of environmental uncertainty and the mediator of resource integration between big data technology skills and business model innovation. 


\subsection{Practical Implications}

The conclusions of this study have the following important implications for enterprise practice. Firstly, big data technical skills can promote novel business model innovation, and novel business model innovation positively affects new product development [15]. With the rapid development of the digital economy and open innovation [23], the amount of data accumulated by enterprises is also increasing rapidly, and traditional business intelligence solutions are increasingly difficult to meet the needs of enterprises [65], while big data analysis can help companies make more accurate and efficient decisions in an environment of uncertainty [66]. Therefore, for enterprises preparing or carrying out novel business model innovation, it is possible to re-examine whether the big data technical skills of enterprises can meet the requirements of enterprises and whether there is room for further improvement, so as to better promote the innovation of novel business models [4]. Secondly, the mediator of resource integration indicates that the rational allocation, bundling and combination of acquired resources by enterprises can drive the innovation of novel business models more directly, while big data technology skills can improve the ability of enterprises to integrate resources. Therefore, companies can use this mechanism to promote novel business model innovation. In addition, in the current scenario where the collaborative economy and block chain are developing faster and faster, and technological progress has brought great challenges to traditional business models [1], policy makers of governments and enterprises can also take advantage of this mechanism to develop policies to address resource challenges in achieving sustainable digital transformation $[67,68]$. Thirdly, enterprises can selectively use big data technical skills according to the changes of the external environment. Big data capability can perceive and capture valuable information resources in environmental uncertainty and improve the dynamic capability of enterprises [31]. Therefore, for those businesses with high environmental uncertainty, they can make full use of big data technical skills to improve the ability of resource integration. For those businesses with low environmental uncertainty, due to small changes in market demand and low possibility of resource portfolio adjustment, the advantages of big data technology skills are not prominent in this scenario.

\subsection{Research Limitations and Future}

This study still has the following limitations which need to be further improved. Firstly, it only discussed the impact of big data technical skills on novel business model innovation. Future research can further explore the impact of big data technical skills on efficient business model innovation. Secondly, although this study collected data on the impact of big data technical skills on novel business model innovation from different time points and different regions, reducing the impact of homology bias, all variables in this study were self-assessed by business managers. This may increase the common method bias, but this study found that the common method bias caused by this method did not have a serious impact on the conclusions of this study through statistical testing. In fact, many scholars such as Kim [69] use employee self-assessment to measure all the variables in their research. Using self-assessment measures for novel business model innovation, combined with the research viewpoints of Chen et al. [70], this study believes that managers' reports on novel business model innovation activities may be more detailed and comprehensive than that of ordinary employees, because management employees have more and richer information than the average employees. Nonetheless, future research could improve this study by using paired data from employees and managers.

Author Contributions: B.D. led the research design, data analysis, and drafted this paper. W.L. assisted the research design and revised the manuscript substantially. All authors have read and agreed to the published version of the manuscript.

Funding: This research was funded by Fujian Social Science Foundation with grant number FJ2021B156, and National Natural Science Foundation of China under grant numbers 41704120.

Institutional Review Board Statement: Not applicable. 
Informed Consent Statement: Not applicable.

Data Availability Statement: Not applicable.

Conflicts of Interest: The authors declare no conflict of interest.

\section{References}

1. Loebbecke, C.; Picot, A. Reflections on societal and business model transformation arising from digitization and big data analytics: A research agenda. J. Strateg. Inf. Syst. 2015, 24, 149-157. [CrossRef]

2. Chesbrough, H. Business model innovation: Opportunities and barriers. Long Range Plan. 2010, 43, 354-363. [CrossRef]

3. Tomi, N.; Bojnec, T.; Simi, B. Corporate sustainability and economic performance in small and medium sized enterprises. J. Clean. Prod. 2015, 108, 603-612.

4. Minatogawa, V.L.F.; Franco, M.M.V.; Rampasso, I.S.; Anholon, R.; Quadros, R.; Durán, O.; Batocchio, A. Operationalizing business model innovation through big data analytics for sustainable organizations. Sustainability 2020, 12, 277. [CrossRef]

5. Amit, R.; Zott, C. Value Creation in E-business. Strateg. Manag. J. 2001, 22, 493-520. [CrossRef]

6. Zott, C.; Amit, R.; Massa, L. The business model: Recent developments and future research. J. Manag. 2011, 37, $1019-1042$.

7. Li, K.; Xia, B.; Chen, Y.; Ding, N.; Wang, J. Environmental uncertainty, financing constraints and corporate investment: Evidence from China. Pac.-Basin Financ. J. 2021, 70, 101665. [CrossRef]

8. Wirtz, B.W.; Pistoia, A.; Ullrich, S. Business models: Origin, development and future research perspectives. Long Range Plan. 2016, 49, 36-54. [CrossRef]

9. Doz, Y.L.; Kosonen, M. Embedding strategic agility: A leadership agenda for accelerating business model renewal. Long Range Plan. 2010, 43, 370-382. [CrossRef]

10. Augier, M.; Teece, D.J. Dynamic capabilities and the role of managers in business strategy and economic performance. Organ. Sci. 2009, 20, 410-421. [CrossRef]

11. Cuzzocrea, A. Supporting OLAP-Based Big Data Analytics over Data-Intensive Business Processes: Issues, Models, Proposals, and a Real-Life Framework. In Proceedings of the CIKM 2018 Workshops Co-Located with 27th ACM International Conference on Information and Knowledge Management, Torino, Italy, 22 October 2018; Volume 2482.

12. Gupta, M.; George, J.F. Toward the development of a big data analytics capability. Inf. Manag. 2016, 53, 1049-1064. [CrossRef]

13. Olabode, O.E.; Boso, N.; Hultman, M.; Leonidou, C.N. Big data analytics capability and market performance: The roles of disruptive business models and competitive intensity. J. Bus. Res. 2022, 139, 1218-1230. [CrossRef]

14. Ciampi, F.; Demi, S.; Magrini, A.; Marzi, G.; Papa, A. Exploring the impact of big data analytics capabilities on business model innovation: The mediating role of entrepreneurial orientation. J. Bus. Res. 2021, 123, 1-13. [CrossRef]

15. Sun, B.; Liu, Y. Business model designs, big data analytics capabilities and new product development performance: Evidence from China. Eur. J. Innov. Manag. 2020, 24, 1162-1183. [CrossRef]

16. Ahmed, R.R.; Kyriakopoulos, G.L.; Streimikiene, D.; Streimikis, J. Drivers of Proactive Environmental Strategies: Evidence from the Pharmaceutical Industry of Asian Economies. Sustainability 2021, 13, 9479. [CrossRef]

17. Sirmon, D.G.; Hitt, M.A.; Ireland, R.D. Managing firm resources in dynamic environments to create value: Looking inside the black box. Acad. Manag. Rev. 2007, 32, 273-292. [CrossRef]

18. Shao, S.; Hu, Z.; Cao, J.; Yang, L.; Guan, D. Environmental regulation and enterprise innovation: A review. Bus. Strategy Environ. 2020, 29, 1465-1478. [CrossRef]

19. Zott, C.; Amit, R. Business model design: An activity system perspective. Long Range Plan. 2010, 43, 216-226. [CrossRef]

20. Maklan, S.; Knox, S. Dynamic capabilities: The missing link in CRM investments. Eur. J. Mark. 2009, 43, 1392-1410. [CrossRef]

21. Bettencourt, L.A.; Brown, S.W. Role stressors and customer-oriented boundary-spanning behaviors in service organizations. J. Acad. Mark. Sci. 2003, 31, 394-408. [CrossRef]

22. Chen, Z.X.; Tsui, A.S.; Farh, J.L. Loyalty to supervisor vs. organizational commitment: Relationships to employee performance in China. J. Occup. Organ. Psychol. 2002, 75, 339-356. [CrossRef]

23. Skordoulis, M.; Ntanos, S.; Kyriakopoulos, G.L.; Arabatzis, G.; Galatsidas, S.; Chalikias, M. Environmental innovation, open innovation dynamics and competitive advantage of medium and large-sized firms. J. Open Innov. Technol. Mark. Complex. 2020 6, 195. [CrossRef]

24. Chen, X.; Zhang, X. How environmental uncertainty moderates the effect of relative advantage and perceived credibility on the adoption of mobile health services by Chinese organizations in the big data era. Int. J. Telemed. Appl. 2016, 2016, 3618402. [CrossRef] [PubMed]

25. Teece, D.J. Business models, business strategy and innovation. Long Range Plan. 2010, 43, 172-194. [CrossRef]

26. Preston, D.S.; Swink, M.; Chen, D.Q. How the use of big data analytics affects value creation in supply chain management. J. Manag. Inf. Syst. 2015, 32, 4-39.

27. Bharadwaj, A.; El Sawy, O.A.; Pavlou, P.A.; Venkatraman, N. Digital business strategy: Toward a next generation of insights. MIS Q. 2013, 37, 471-482. [CrossRef]

28. Ransbotham, S.; Kiron, D. Analytics as a source of business innovation. MIT Sloan Manag. Rev. 2017, 58, 1-21.

29. Pesqueira, A.; Sousa, M.J.; Rocha, Á. Big Data skills sustainable development in Healthcare and Pharmaceuticals. J. Med. Syst. 2020, 44, 197. [CrossRef] [PubMed] 
30. Teece, D.J.; Pisano, G.; Shuen, A. Dynamic capabilities and strategic management. Strateg. Manag. J. 1997, 18, 509-533. [CrossRef]

31. Mikalef, P.; Krogstie, J. Big Data Governance and Dynamic Capabilities: The Moderating Effect of Environmental Uncertainty. In Proceedings of the 22nd Pacific Asia Conference on Information Systems (PACIS 2018), Yokohama, Japan, 26-30 June 2018.

32. Kwon, O.; Lee, N.; Shin, B. Data quality management, data usage experience and acquisition intention of big data analytics. Int. J. Inf. Manag. 2014, 34, 387-394. [CrossRef]

33. Akter, S.; Wamba, S.F.; Gunasekaran, A.; Dubey, R.; Childe, S.J. How to improve firm performance using big data analytics capability and business strategy alignment? Int. J. Prod. Econ. 2016, 182, 113-131. [CrossRef]

34. Teece, D. Explicating dynamic capabilities: The nature and micro foundations of (sustainable) enterprise performance. Strateg. Manag. J. 2007, 28, 1319-1350. [CrossRef]

35. Penrose, E.T. The Theory of the Firm; Blackwell: London, UK, 1959.

36. Ghasemaghaei, M. The role of positive and negative valence factors on the impact of bigness of data on big data analytics usage. Int. J. Inf. Manag. 2020, 50, 395-404. [CrossRef]

37. Pati, R.K.; Nandakumar, M.K.; Ghobadian, A.; Ireland, R.D.; O’Regan, N. Business model design-performance relationship under external and internal contingencies: Evidence from SMEs in an emerging economy. Long Range Plan. 2018, 51, 750-769. [CrossRef]

38. Agostini, L.; Galati, F.; Gastaldi, L. The digitalization of the innovation process: Challenges and opportunities from a management perspective. Eur. J. Innov. Manag. 2019, 23, 1-12. [CrossRef]

39. Teece, D.J. Business models and dynamic capabilities. Long Range Plan. 2018, 51, 40-49. [CrossRef]

40. Pierce, J.L.; Gardner, D.G.; Cummings, L.L.; Dunham, R.B. Organization-based self-esteem: Construct definition, measurement, and validation. Acad. Manag. J. 1989, 32, 622-648.

41. Li, X.Y. Research on Management Uncertainty Solution Based on Environmental Change by big data Technology. J. Phys. Conf. Ser. 2019, 1345, 022063.

42. Girod, S.J.G.; Whittington, R. Reconfiguration, restructuring and firm performance: Dynamic capabilities and environmental dynamism. Strateg. Manag. J. 2017, 38, 1121-1133. [CrossRef]

43. Grönroos, C. Value co-creation in service logic: A critical analysis. Mark. Theory 2011, 11, 279-301. [CrossRef]

44. Van Rijmenam, M.; Erekhinskaya, T.; Schweitzer, J.; Williams, M.-A. Avoid being the Turkey: How big data analytics changes the game of strategy in times of ambiguity and uncertainty. Long Range Plan. 2019, 52, 101841. [CrossRef]

45. Osiyevskyy, O.; Dewald, J. Explorative versus exploitative business model change: The cognitive antecedents of firm-level responses to disruptive innovation. Strateg. Entrep. J. 2015, 9, 58-78. [CrossRef]

46. Podsakoff, P.M.; MacKenzie, S.B.; Lee, J.Y.; Podsakoff, N.P. Common method biases in behavioral research: A critical review of the literature and recommended remedies. J. Appl. Psychol. 2003, 88, 879-903. [CrossRef] [PubMed]

47. Nunnally, J.C. Psychometric Theory, 2nd ed.; McGraw-Hill: New York, NY, USA, 1978.

48. Miller, D. The structural and environmental correlates of business strategy. Strateg. Manag. J. 1987, 8, 55-76. [CrossRef]

49. Jansen, J.J.P.; Van Den Bosch, F.A.J.; Volberda, H.W. Exploratory innovation, exploitative innovation, and performance: Effects of organizational antecedents and environmental moderators. Manag. Sci. 2006, 52, 1661-1674. [CrossRef]

50. Zott, C.; Amit, R. Business model design and the performance of entrepreneurial firms. Organ. Sci. 2007, 18, 181-199. [CrossRef]

51. Baron, R.M.; Kenny, D.A. The moderator-mediator variable distinction in social psychological research: Conceptual, strategic, and statistical considerations. J. Personal. Soc. Psychol. 1986, 51, 1173. [CrossRef]

52. Preacher, K.J.; Rucker, D.D.; Hayes, A.F. Addressing moderated mediation hypotheses: Theory, methods, and prescriptions. Multivar. Behav. Res. 2007, 42, 185-227. [CrossRef]

53. Hayes, A.F. An index and test of linear moderated mediation. Multivar. Behav. Res. 2015, 50, 1-22. [CrossRef] [PubMed]

54. Wang, Y.; Hajli, N. Exploring the path to big data analytics success in healthcare. J. Bus. Res. 2017, 70, 287-299. [CrossRef]

55. Corrales-Garay, D.; Mora-Valentín, E.M.; Ortiz-de-Urbina-Criado, M. Entrepreneurship through open data: An opportunity for sustainable development. Sustainability 2020, 12, 5148. [CrossRef]

56. Yun, J.H.J.; Zhao, X.; Wu, J.; Yi, J.C.; Park, K.; Jung, W. Business model, open innovation, and sustainability in car sharing industry-Comparing three economies. Sustainability 2020, 12, 1883. [CrossRef]

57. Del Vecchio, P.; Mele, G.; Ndou, V.; Secundo, G. Open innovation and social big data for sustainability: Evidence from the tourism industry. Sustainability 2018, 10, 3215. [CrossRef]

58. Pohlisch, J. Internal open innovation-Lessons learned from internal crowdsourcing at SAP. Sustainability 2020, $12,4245$. [CrossRef]

59. Alvarez-Meaza, I.; Pikatza-Gorrotxategi, N.; Rio-Belver, R.M. Sustainable business model based on open innovation: Case study of Iberdrola. Sustainability 2020, 12, 10645. [CrossRef]

60. Yun, J.J.; Zhao, X.; Park, K.B.; Shi, L. Sustainability condition of open innovation: Dynamic growth of alibaba from SME to large enterprise. Sustainability 2020, 12, 4379. [CrossRef]

61. Yuana, R.; Prasetio, E.A.; Syarief, R.; Arkeman, Y.; Suroso, A.I. System Dynamic and Simulation of Business Model Innovation in Digital Companies: An Open Innovation Approach. J. Open Innov. Technol. Mark. Complex. 2021, 7, 219. [CrossRef]

62. Tian, Q.; Zhang, S.; Yu, H.; Cao, G. Exploring the factors influencing business model innovation using grounded theory: The case of a Chinese high-end equipment manufacturer. Sustainability 2019, 11, 1455. [CrossRef]

63. Peñarroya-Farell, M.; Miralles, F. Business model dynamics from interaction with open innovation. J. Open Innov. Technol. Mark. Complex. 2021, 7, 81. [CrossRef] 
64. Fukawa, N.; Zhang, Y.; Erevelles, S. Dynamic Capability and Open-Source Strategy in the Age of Digital Transformation. J. Open Innov. Technol. Mark. Complex. 2021, 7, 175. [CrossRef]

65. Dayana, B.D.; Samanta, A.; Ranganathan, N.; Venkatachalam, K.; Jain, N.A. comprehensive approach to visualize industrial data set to meet business intelligence requirements using statistical models and big data analytics. Int. J. Recent Technol. Eng. 2019, 7, 1437-1443.

66. Manikam, S.; Sahibudin, S.; Selamat, H. Big Data Analytics Initiatives Using Business Intelligence Maturity Model Approach in Public Sector. Adv. Sci. Lett. 2017, 23, 4097-4100. [CrossRef]

67. Bojnec, Š.; Tomšič, N. Corporate sustainability and enterprise performance: The mediating effects of internationalization and networks. Int. J. Product. Perform. Manag. 2020, 70, 21-39. [CrossRef]

68. Kamali Saraji, M.; Streimikiene, D.; Kyriakopoulos, G.L. Fermatean fuzzy CRITIC-COPRAS method for evaluating the challenges to Industry 4.0 adoption for a sustainable digital transformation. Sustainability 2021, 13, 9577. [CrossRef]

69. Kim, T.Y.; Hon, A.H.Y.; Crant, J.M. Proactive personality, employee creativity, and newcomer outcomes: A longitudinal study. J. Bus. Psychol. 2009, 24, 93-103. [CrossRef]

70. Chen, X.P.; Eberly, M.B.; Chiang, T.J.; Farh, J.L.; Cheng, B.S. Affective trust in Chinese leaders: Linking paternalistic leadership to employee performance. J. Manag. 2014, 40, 796-819. [CrossRef] 